Article

\title{
Novel Mixed-Type Inhibitors of Protein Tyrosine Phosphatase 1B. Kinetic and Computational Studies
}

\author{
Marie Jazmín Sarabia-Sánchez ${ }^{1}$, Pedro Josué Trejo-Soto ${ }^{2}$, José Miguel Velázquez-López ${ }^{2}$, \\ Carlos Carvente-García ${ }^{2}$, Rafael Castillo ${ }^{2}$, Alicia Hernández-Campos ${ }^{2}$, \\ Claudia Avitia-Domínguez ${ }^{1}$, Daniel Enríquez-Mendiola ${ }^{1}$, Erick Sierra-Campos ${ }^{3}$ (D), \\ Mónica Valdez-Solana ${ }^{3}$, José Manuel Salas-Pacheco ${ }^{4}$ and Alfredo Téllez-Valencia ${ }^{1, *}$ \\ 1 Facultad de Medicina y Nutrición, Universidad Juárez del Estado de Durango, \\ Av. Universidad y Fanny Anitúa S/N, Durango, Durango C.P. 34000, Mexico; \\ marie_sarabia@hotmail.com (M.J.S.-S.); avitiaclaudia@gmail.com (C.A.-D.); \\ qfb.dan.enriquez@hotmail.com (D.E.-M.) \\ 2 Facultad de Química, Departamento de Farmacia, Universidad Nacional Autónoma de México, Ciudad de \\ México C.P. 04510, Mexico; Piter_jo@comunidad.unam.mx (P.J.T.-S.); miguelzx42@hotmail.com (J.M.V.-L.); \\ krbnt@hotmail.com (C.C.-G.); rafaelc@unam.mx (R.C.); hercam@unam.mx (A.H.-C.) \\ 3 Facultad de Ciencias Químicas, Universidad Juárez del Estado de Durango, Av. Artículo 123 S/N Fracc. \\ Filadelfia, Gómez Palacio, Durango C.P. 35010, Mexico; ericksier@gmail.com (E.S.-C.); \\ valdezandyval@gmail.com (M.V.-S.) \\ 4 Instituto de Investigación Científica, Universidad Juárez del Estado de Durango, Av. Universidad S/N, \\ Durango, Durango C.P. 34000, Mexico; jsalas_pacheco@hotmail.com \\ * Correspondence: atellez@ujed.mx; Tel./Fax: +52-618-812-1687
}

Received: 21 November 2017; Accepted: 16 December 2017; Published: 20 December 2017

\begin{abstract}
The Atlas of Diabetes reports 415 million diabetics in the world, a number that has surpassed in half the expected time the twenty year projection. Type 2 diabetes is the most frequent form of the disease; it is characterized by a defect in the secretion of insulin and a resistance in its target organs. In the search for new antidiabetic drugs, one of the principal strategies consists in promoting the action of insulin. In this sense, attention has been centered in the protein tyrosine phosphatase 1B (PTP1B), a protein whose overexpression or increase of its activity has been related in many studies with insulin resistance. In the present work, a chemical library of 250 compounds was evaluated to determine their inhibition capability on the protein PTP1B. Ten molecules inhibited over the 50\% of the activity of the PTP1B, the three most potent molecules were selected for its characterization, reporting Ki values of 5.2, 4.2 and $41.3 \mu \mathrm{M}$, for compounds 1, 2, and 3, respectively. Docking and molecular dynamics studies revealed that the three inhibitors made interactions with residues at the secondary binding site to phosphate, exclusive for PTP1B. The data reported here support these compounds as hits for the design more potent and selective inhibitors against PTP1B in the search of new antidiabetic treatment.
\end{abstract}

Keywords: protein tyrosine phosphatase 1B; type 2 diabetes; benzimidazole derivatives; enzyme inhibition; docking; molecular dynamics

\section{Introduction}

In its sixth edition, the Atlas of Diabetes reported 415 million diabetics worldwide, surpassing in half the time the twenty year projection [1,2]. Type 2 diabetes is the most frequent type of the disease; it is characterized by a defect in the secretion of insulin and resistance in its target organs. For its treatment there are several hypoglycemic agents, these have different mechanisms of action such as an increase in insulin production, decrease of the hepatic glucose production, limiting the 
absorption of postprandial glucose, and inhibiting gluconeogenesis [3]. Nevertheless, after 3 or 4 years of treatment the efficacy of these drugs is diminished, even with combinations among them, and insulin administration becomes necessary [4]. Therefore, there is an urgency for new drugs with other mechanisms of action that can provide different alternative treatments for type 2 diabetes.

To this end, one of the main strategies consists in promoting the action of insulin [5], and the attention has been focused in the protein tyrosine phosphatase 1B (PTP1B), a protein which overexpression and increase in its activity has been related in many studies with insulin resistance [6-8]. PTP1B works specifically by dephosphorylating residues of phosphotyrosine both from the insulin receptor (IR) and insulin receptor substrate (IRS) [9]. In a recent study, Munc18c was discovered as a substrate for the PTP1B, it is related to the regulation of glucose transporter GLUT4 in adipocytes, allowing or impeding, the insertion of the vesicle into the membrane [10]. These and other evidences [11-13] validate this enzyme as a potential therapeutic target against type 2 diabetes.

Since the establishment of the PTP1B as a biological target, there has been an effort to obtain inhibitors of its activity $[14,15]$. Different strategies such as diverse computational techniques, natural products research, and medicinal chemistry have been applied in the search for PTP1B inhibitors [16-20]. The first efforts to obtain inhibitors consisted in the search for phosphotyrosine (pTyr) mimetics such as difluoromethylene phosphate (DFMP) [21-24], carboxylic acids [25-28], 1,2,5-thiazolidin-3-one 1,1-dioxide (TZD), and the (S)-isomer of isothiazolidinone ((S)-IZD) [24,29], which achieve different degrees of inhibition of the enzyme. Furthermore, natural products and some derivatives have been reported too [30,31], as well as small molecules optimized from the previous ones [23,32]. Nevertheless, finding a potent, selective and with good oral availability molecule is still a challenge to be overcome.

The highly conserved catalytic site in the phosphatases family hinders the finding of a selective molecule, especially against its closest homologous T-cell protein tyrosine phosphatase (TCPTP) [33,34]. One strategy is to seek interactions with specific sites of the PTP1B [35-37]. In this sense, the enzyme has two aryl phosphate binding sites, a catalytic site with high affinity that contains the Cys215, and another one with low affinity that contains the Arg24 and Arg254. The former, denominated as site B, is specific for PTP1B. A few molecules based on this concept have reached clinical trials, among which ertiprotafib, ISIS 113715 and trodusquemine may be highlighted [38-40], however they did not continue to later stages.

In the present work, a chemical library composed by 250 compounds was evaluated to determine their inhibition capabilities on the PTP1B. The three most potent molecules were selected for further characterization, including their mechanism and inhibition constants. Structural studies of the PTP1B-inhibitor interaction were performed through docking and molecular dynamics simulations as well as an estimation of their drug-like and toxicological properties.

\section{Results and Discussion}

\subsection{Compounds Screening}

With the aim of finding new compounds capable of inhibiting PTP1B activity, a chemical library of 250 small molecules was evaluated at $200 \mu \mathrm{M}$. From the total of compounds evaluated, 26 inhibited the enzyme activity by more than $60 \%$, 26 of them between $31-59 \%$ (Table S1), and the rest below $30 \%$. The characteristics of the ten most potent compounds are shown in Table 1, and their structures in Figure 1.

According to their structure, the three most potent PTP1B inhibitors (compounds 1, 2 and 3) all contain a benzimidazole nucleus. The analysis suggests that bulky substituents are required at positions 2 ( 1 vs. 9 and 10$)$ and $5(\mathbf{1}$ vs. 10) of the benzimidazole skeleton to increase their inhibition capability. The presence of the benzimidazole nucleus in the structure of the PTP1B inhibitors has been reported before, nevertheless, due to their substituents, they showed permeability and specificity problems with respect to other phosphatases [41-43]. 
Table 1. The ten most potent PTP1B inhibitors.

\begin{tabular}{cccccccc}
\hline Molecule & $\mathbf{M W}^{\mathbf{a}}$ & $\mathbf{H B D}^{\mathbf{a}}$ & $\mathbf{H B A}^{\mathbf{a}}$ & $\mathbf{L o g P}^{\mathbf{a}}$ & $\begin{array}{c}\text { Drug } \\
\text { Likeness }\end{array}$ & $\begin{array}{c}\text { Binding Energy } \\
\mathbf{( K c a l / m o l )}\end{array}$ & $\begin{array}{c}\text { \% Inhibition } \\
(\mathbf{2 0 0} \boldsymbol{\mu M} \mathbf{M}\end{array}$ \\
\hline $\mathbf{1}$ & 567.27 & 2 & 7 & 6.68 & 1.07 & -4.20 & 100 \\
$\mathbf{2}$ & 466.96 & 2 & 6 & 6.00 & 0.86 & -4.99 & 99 \\
$\mathbf{3}$ & 424.59 & 2 & 5 & 5.53 & 0.66 & -4.47 & 92 \\
$\mathbf{4}$ & 356.36 & 1 & 8 & 2.94 & -0.49 & -3.70 & 88 \\
$\mathbf{5}$ & 496.32 & 0 & 9 & 5.13 & 0.18 & -4.02 & 85 \\
$\mathbf{6}$ & 498.47 & 2 & 8 & 4.26 & -0.12 & -5.24 & 84 \\
$\mathbf{7}$ & 499.94 & 1 & 7 & 4.95 & 0.41 & -3.49 & 80 \\
$\mathbf{8}$ & 446.51 & 1 & 5 & 5.80 & 0.05 & -3.98 & 74 \\
$\mathbf{9}$ & 384.64 & 1 & 5 & 4.36 & 0.76 & -3.99 & 70 \\
$\mathbf{1 0}$ & 356.83 & 1 & 4 & 4.35 & 0.08 & -4.01 & 65 \\
\hline
\end{tabular}

a Server FAFDrugs [44], filter Drug-like soft was used: MW 100-600; HBD $\leq 5 ; \mathrm{HBA} \leq 12$; $\operatorname{LogP}-3$ to 6 . $^{\mathrm{b}}$ Server Molsolf [45], Drug-Likeness score was determined, values between -1 to 2 are accepted.

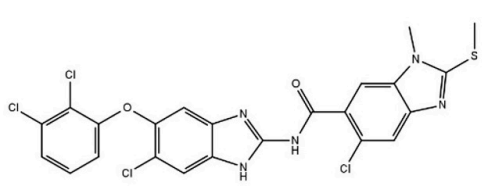

1<smiles>CC(CCC1CCCC1C1CCC(O)CC1)C1CCC2OCCC2C1</smiles>

4<smiles>COc1cc2c(cc1OC)C(=O)N(c1ccccc1)C(SCC(=O)Nc1ccc(F)c(Br)c1)N2</smiles>

7

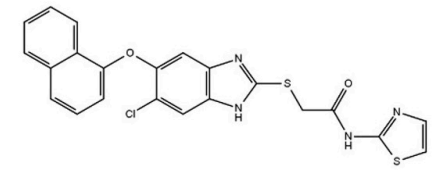

2<smiles>CC1CC(C)CC(NC2CCC(C3CNC(C4CCC(NC(C)(C)C(C)C)CC4)C3)C2)C1</smiles>

5<smiles>CCCCCC1CCC(C(C)(CCC2CC(C)CC(C)C2)CSC2CCCCC2C)CC1</smiles>

8<smiles>CS(=O)c1nc2cc(Cl)c(Oc3cccc4ccccc34)cc2[nH]1</smiles><smiles>CC(F)(F)C(=O)Nc1nc2cc(Oc3cccc(Cl)c3Cl)c(Cl)cc2[nH]1</smiles>

3<smiles>CCCC1CC(C)OC2CC(OC(C)C(=O)NP(C)(=O)N(C)C3CCCC(C(F)(F)F)C3)CCC12</smiles>

6<smiles></smiles>

9

10

Figure 1. Chemical structures of the ten most potent PTP1B inhibitors. The number of each compound corresponds to that indicated in Table 1.

Regarding molecules 5, 6 and 8 they have in their structure substituents that have been reported before in PTP1B inhibitors [28]. Molecules 4 and 7 represent a new chemical nucleus, which extends the structural diversity of molecules that inhibit PTP1B reported to date. Finally, molecules 1, 2 and 3 were selected to characterize their inhibition mechanism by enzymatic kinetics, docking and molecular dynamics. 


\subsection{Kinetic Studies}

Analysis of the plots at different substrate and fixed inhibitor concentrations indicated that the three compounds showed a mixed type inhibition mechanism (Figure 2a-c). This suggests that the three molecules are able to recognize both the free enzyme and the enzyme-substrate complex, generating the enzyme-substrate-inhibitor ternary complex, which is inactive [46] (Figure 2d). Something interesting to highlight is that compound $\mathbf{1}$ had an $\alpha$ value close to 1 suggesting that it recognizes, almost with the same affinity, both the free enzyme and the enzyme-substrate complex [46], whilst in compounds 2 and 3 this value was close to 3 , suggesting a three times lower affinity with respect to the enzyme-substrate complex. These results suggest that the noncompetitive component of these inhibitors is stronger than the competitive component into inhibition mechanism, where the values of $\mathrm{Ki}$ and $\mathrm{IC}_{50}$ in our study were very similar [47]. The kinetic parameters were obtained from the adjustment of the data to the correspondent equation (Table 2).

The ChEMBL database from the Bioinformatics European Institute [48], reported 5854 compounds active against PTP1B. Of interest of this work, 30 of them show a reported mixed type inhibition mode, but only eight presented a Ki value lower than $5 \mu \mathrm{M}$ [49-61]. Something important is that the chemical structures of these inhibitors are totally different from those reported here, and include DMFS derivatives [58], benzoic acid-based derivatives [57], insulin-mimetic selaginellins [59], pentacyclic acid triterpenoids [52], and oleanilic acid derivatives [61]. Also interesting is that $\alpha$ value reported was in the same range as for compounds $\mathbf{1 , 2}$, and 3.

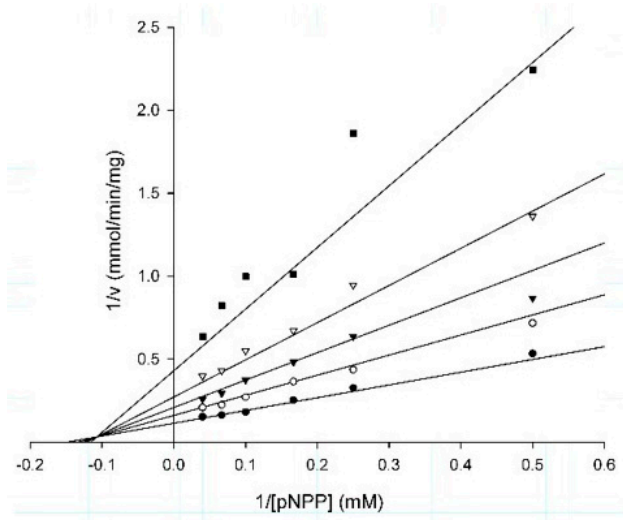

(a)

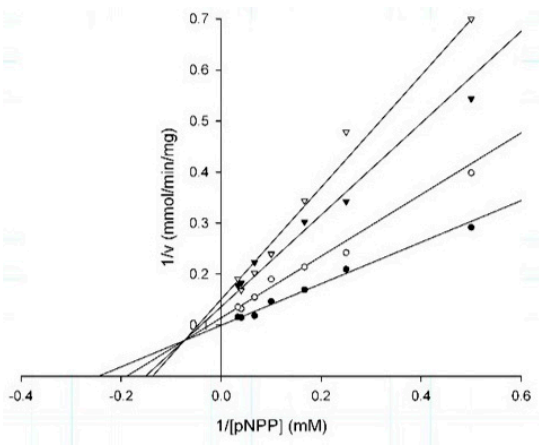

(c)

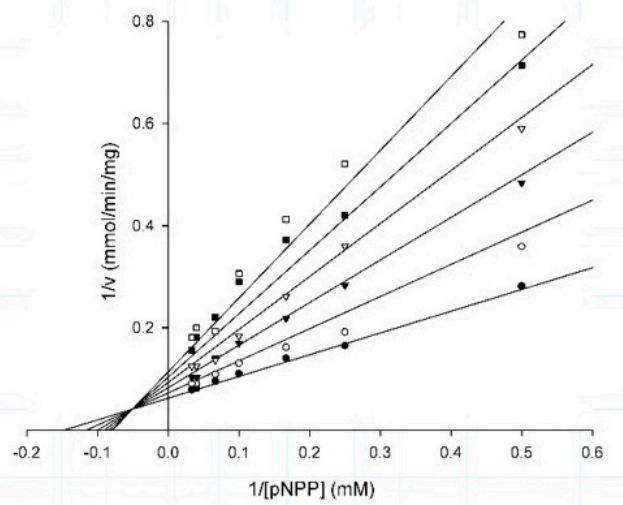

(b)

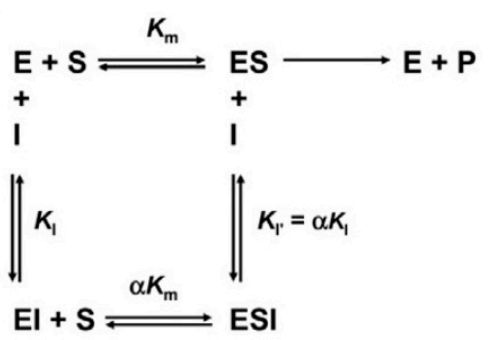

(d)

Figure 2. Lineweaver-Burk plots of (a) compound 1 at 0 (filled circles), 3 (open circle), 6 (filled triangle), 10 (open triangle), and $20 \mu \mathrm{M}$ (filled squares); (b) compound 2 at 0 (filled circles), 2 (open circle), 4 (filled triangles), 6 (open triangles), 8 (filled squares), and $10 \mu \mathrm{M}$ (open squares); and (c) compound 3 at 0 (filled circles), 20 (open circle), 50 (filled triangles), and $70 \mu \mathrm{M}$ (open triangles); (d) kinetic model for mixed type inhibition. In the scheme, E corresponds to free enzyme; $\mathrm{S}$ is the substrate; ES is the enzyme-substrate complex; EI corresponds to the enzyme-inhibitor complex; ESI is the enzyme-substrate-inhibitor ternary complex; and $\mathrm{P}$ is the reaction product. 
Table 2. Type of inhibition and kinetic parameters for PTP1B inhibitors.

\begin{tabular}{ccccccc}
\hline Molecule & $\mathbf{K i}(\mu \mathbf{M})$ & $\mathbf{I C}_{\mathbf{5 0}}(\mu \mathbf{M})$ & $\boldsymbol{\alpha}$ & $\mathbf{V}_{\max }(\mu \mathbf{m o l} / \mathbf{m i n} / \mathbf{m g})$ & $\mathbf{K m}(\mathbf{m M})$ & Inhibition Type \\
\hline $\mathbf{1}$ & 5.2 & 7.5 & 1.4 & 8.8 & 6.7 & Mixed \\
$\mathbf{2}$ & 4.2 & 8.4 & 2.9 & 16 & 6.8 & Mixed \\
$\mathbf{3}$ & 41.3 & 31.3 & 3.3 & 10 & 4.1 & Mixed \\
\hline
\end{tabular}

With respect to available drugs for the treatment of type 2 diabetes, classified in a general way as sulfonylureas, meglitidines, biguanides, thiazolidinediones, $\alpha$-glucosidase inhibitors, glucagon-like peptide- 1 receptor agonists, dipeptidyl peptidase- 4 inhibitors, sodium glucose transporter-2 inhibitors, synthetic amylin analogues, and dopamine-2 agonists [62,63], none of them are benzimidazole derivatives, on the contrary, they are made up of different chemical groups such as sulfonylureas, guanidines, thiazolidinediones, disaccharides, glucose derivatives, peptidomimetics, among others [63]. The above makes the compounds 1, 2 and $\mathbf{3}$ novel structural proposals.

After kinetic studies, the binding mode and the type of interactions between the inhibitors and the PTP1B were analyzed by docking and molecular dynamics studies.

\subsection{Molecular Docking}

Before the molecular docking of the inhibitors, the protocol was validated through the binding mode of the inhibitor reported in the crystallographic structure used [64]. The RMSD value obtained from the modeling using Glide and the crystallographic complex was of $0.24 \AA$, which indicated that the docking protocol was done correctly (data not shown). After this, the three inhibitors were docked, obtaining binding energies of $-4.2,-5.0$ and $-4.5 \mathrm{Kcal} / \mathrm{mol}$ for compounds $\mathbf{1}, \mathbf{2}$, and 3, respectively.

As for their binding modes, the three compounds formed interactions with residues from the secondary binding site to phosphate (Arg24, Arg254, Gly259, Gln262 and Asp48) [65]. In the three cases, the molecules block the cavity of the catalytic site without interacting with the signature residues of phosphatases.

The interaction with Asp48 has been reported before in different crystallographic structures of PTP1B in complex with other benzimidazole derivatives [41-43]. Additionally the interaction of the benzimidazole nucleus with the Gln262 found in the three inhibitors has been also reported $[66,67]$, (Figure 3). A more detailed analysis of the interactions between these molecules and the enzyme were performed by molecular dynamic studies, the results are described below.

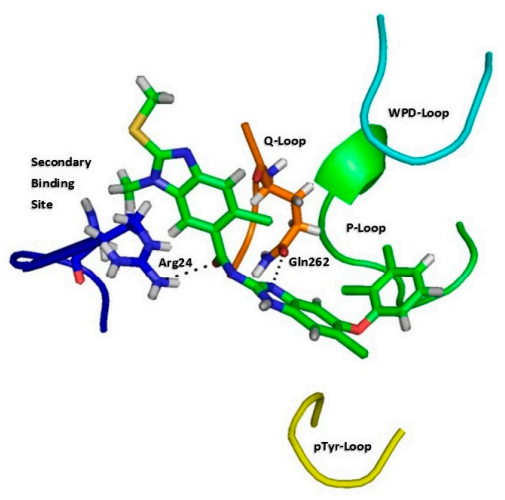

1

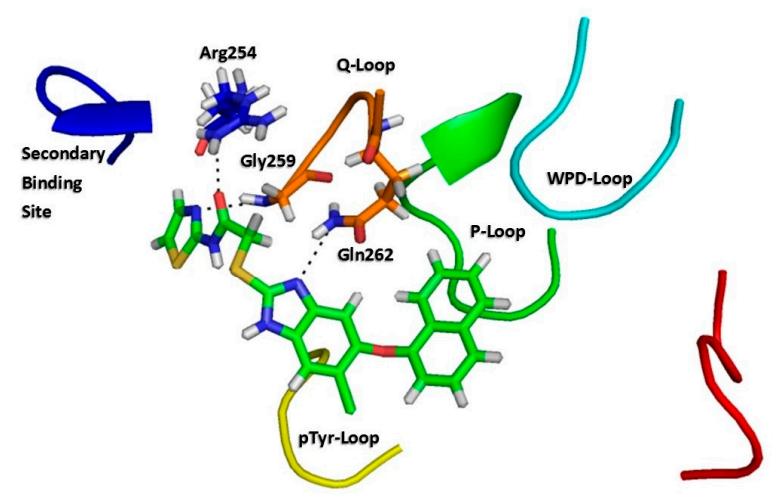

2

Figure 3. Cont. 


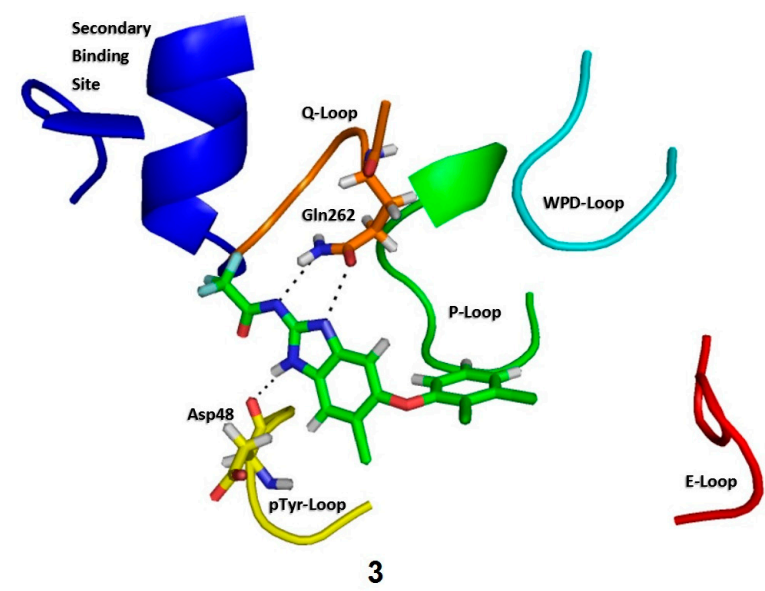

Figure 3. Binding mode of compounds 1, 2 and 3 in PTP1B. Loops are highlighted as follows: P loop (green), WPD loop (cyan), Q262 loop (orange), pTyr46 loop (yellow), and E loop (red). Secondary phosphate binding site is highlighted in blue.

\subsection{Molecular Dynamics Simulations}

The complexes obtained by molecular docking were submitted to a simulation of $10 \mathrm{~ns}$. The total energy variation plots showed that the energy variation was around $-12 \mathrm{Kcal} / \mathrm{mol}$, which indicate that the average energy remains constant and there is structural stability of the complexes (Figure S1). The RMSD analysis showed that the three complexes had fluctuations in the first $3500 \mathrm{ps}$, achieving the stability from the 4000 ps up to the 10,000 ps without exceeding a $0.30 \AA$ variation (Figure S2). It also was observed the influence of the inhibitors over the protein, with the variation of the RMSD in comparison with the protein alone.

The analysis of the binding energies showed that the compound 1 presented the best global binding energy, followed by compounds 2 and 3, which is in accordance with the inhibitory activity observed in the kinetic studies. The same situation was repeated in the individual values of the different components of the global energy, except in the electrostatic one, where compound 2 obtained the highest value (Table 3).

Table 3. Binding free energies determined by the MMPBSA method, and hydrogen bonds of the protein-ligand complexes.

\begin{tabular}{cccccccc}
\hline \multirow{2}{*}{ Complex } & \multicolumn{3}{c}{ Energy (kcal/mol) } & \multicolumn{3}{c}{ Hydrogen Bonds } \\
\cline { 2 - 8 } & $\begin{array}{c}\text { Van der } \\
\text { Waals Energy }\end{array}$ & $\begin{array}{c}\text { Electrostatic } \\
\text { Energy }\end{array}$ & $\begin{array}{c}\text { Polar Solvation } \\
\text { Energy }\end{array}$ & $\begin{array}{c}\text { SASA } \\
\text { Energy }\end{array}$ & $\begin{array}{c}\Delta G \\
\text { Binding }\end{array}$ & Range & Average \\
\hline PTP1B-1 & -47.56 & -17.97 & 32.34 & -4.17 & -37.36 & $0-3$ & 3 \\
PTP1B-2 & -35.46 & -27.01 & 33.57 & -3.54 & -32.43 & $0-5$ & 4 \\
PTP1B-3 & -29.50 & -3.63 & 12.33 & -2.93 & -23.74 & $0-4$ & 2 \\
\hline
\end{tabular}

The structural analysis along the simulation time showed that the three molecules formed interactions, being the most important, the hydrophobic type interaction with the Asp48 and compound 1 ( $70 \%$ of occupancy), meanwhile compound 2 interacted with Phe182 ( $87 \%$ of occupancy). Compound 3 formed hydrogen bonds with Ala264, Gln262, and Arg24, as well as a hydrophobic interaction with Phe182, all of them with occupancy of 40\% (Figure 4). Something interesting to highlight is that the interactions formed by the three inhibitors include important residues for the enzyme function like Gln262 and the Asp48, without having interactions with the denominated signature residues of the phosphatases $(\mathrm{H} / \mathrm{V}) \mathrm{CXXGXXR(S/T)}[34,68]$. In this context, several studies have shown that selectivity against TCPTP can be achieved by interactions with residues such as Arg24, Arg47, Asp48, Arg254, Met258, and Gln262 [35,65]. Additionally, we investigated their binding mode 
in TCTPT by molecular docking, finding that the three compounds made interactions with different residues of the enzyme (Figure S3). In conclusion, computational studies suggest that these inhibitors could be selective for PTP1B.

\section{Complex PTP1B - 1}
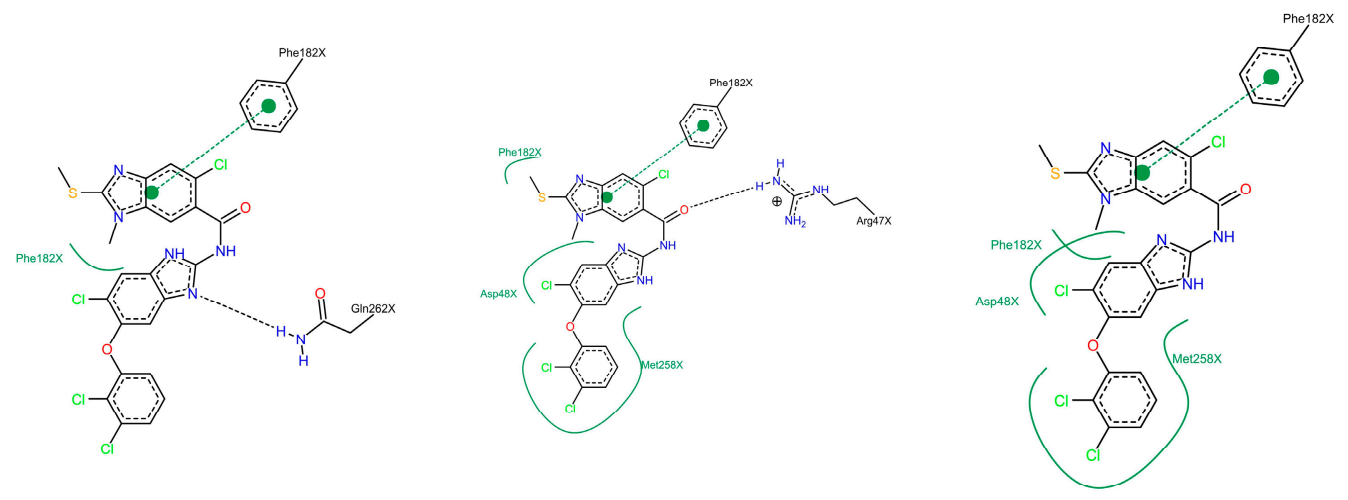

\section{Complex PTP1B - 2}
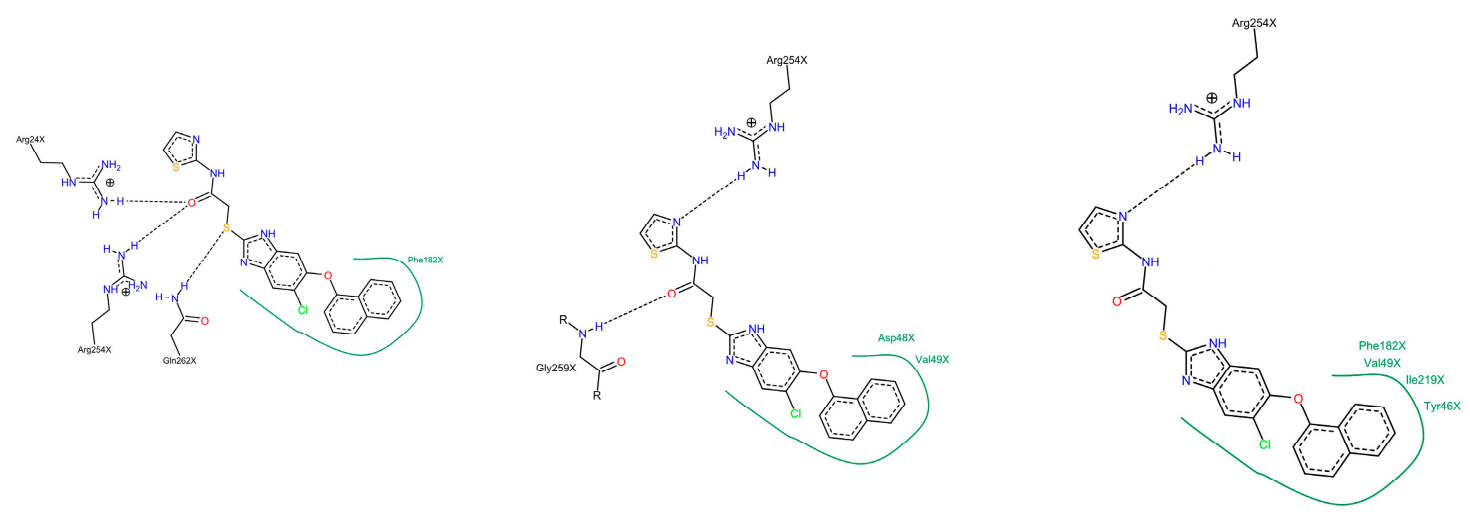

Complex PTP1B - 3
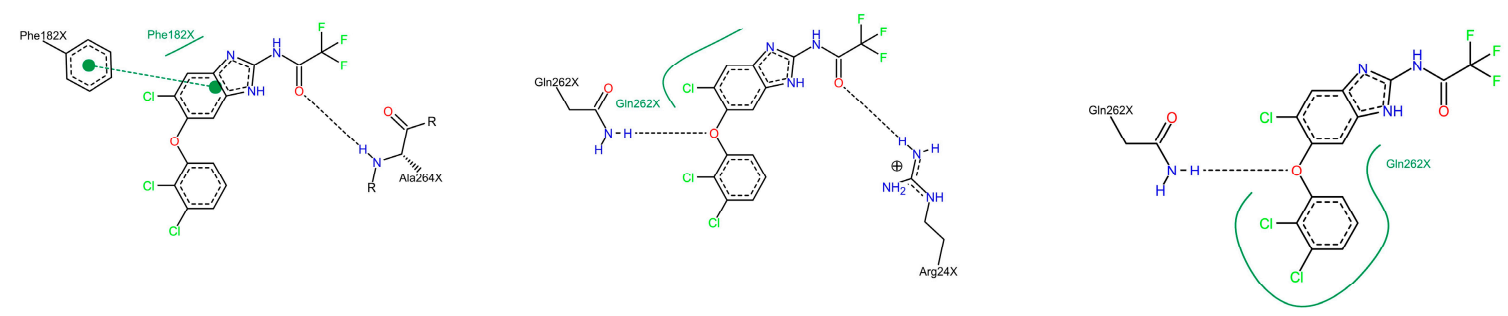

Figure 4. Two dimensional maps of interaction from the complexes PTP1B-1, PTP1B-2, and PTP1B-3. The image shows interactions at different times during entire dynamics: beginning, stabilized (4 ns), and final (10 ns). Hydrogen bonds between protein and ligand are drawn as dashed lines. Hydrophobic contacts are represented by means of spline sections highlighting the hydrophobic parts of the ligand and the name of the contacting amino acid. Maps were generated in Server Poseview (http:/ / proteinsplus.zbh.uni-hamburg.de/\#poseview). 


\subsection{Physicochemical and Drug-Like properties}

The in silico evaluation of the physicochemical and drug-like parameters suggested that these molecules possess the necessary chemical features to potentially have an acceptable oral absorption [69-71] (Table 1 and Figure 5).

Molecule 1
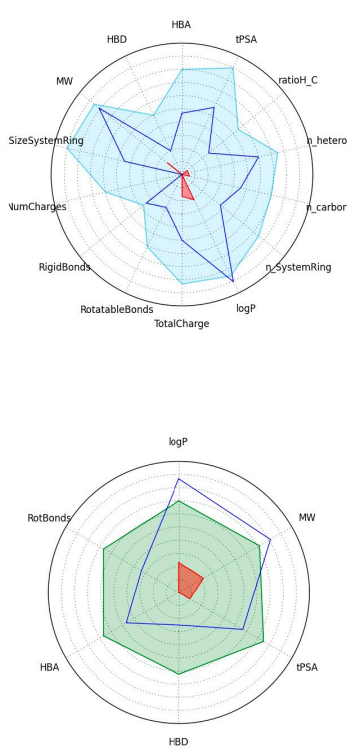

Molecule 2

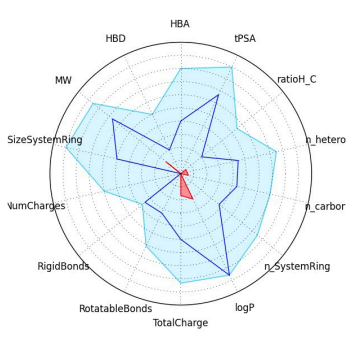

(a)

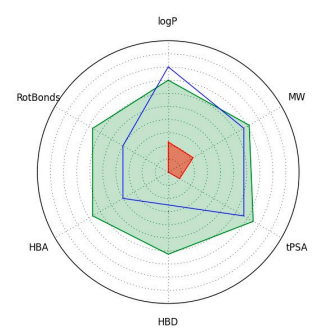

Molecule 3
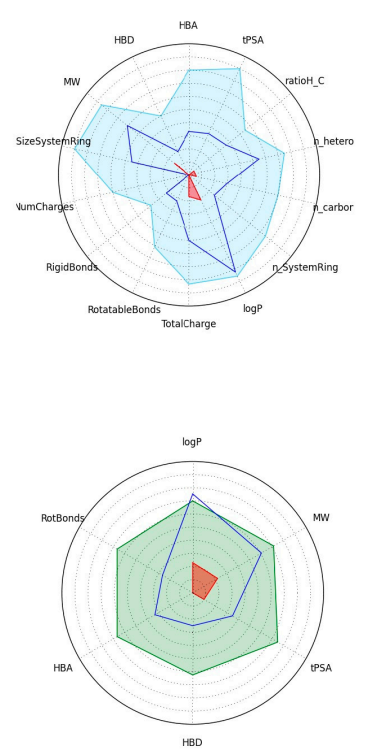

(b)

Figure 5. (a) Scheme of PhysChem Filter Positioning, compound values (blue line) should fall within the drug-like filter area (light blue); (b) Scheme of Oral Absorption Estimation, compound values (blue line) should fall within RO5 and Veber rules area (light green). The logarithm of the partition coefficient between n-octanol and water, $\log \mathrm{P}$; Molecular Weight, MW; Hydrogen Bond Donnors, HBD; Hydrogen Bond Acceptors, HBA; topological Polar Surface Area, tPSA; het/carbon atoms ratio, ratioH/C; Number of Heteroatoms, n_hetero; Number of Carbon Atoms, n_carbor; Number of Smallest Set of Smallest Rings, n_SystemRing.

\subsection{Toxicological Evaluation}

An important point to analyze during the development of any new drug is the toxicological profile of the molecule. In this matter, using different softwares available online, a detailed study to predict the toxicological potential of these three inhibitors was performed. The estimation of the lethal dose $50\left(\mathrm{LD}_{50}\right)$ suggested that the three molecules are moderately toxic. Nevertheless, according to software evaluation, there are no toxic fragments reported in their structure, neither biological targets that can denote toxicity. With respect to their mutagenic, tumorigenic, irritability and reproductive effects, the only molecule that did not show any of these features was compound 2 (Table 4).

Taking into account all the data presented, compound $\mathbf{2}$ is the most viable option to continue with its optimization since it showed the best kinetic and predicted physicochemical and toxicological features. However, compounds $\mathbf{1}$ and $\mathbf{3}$ are still interesting structures that provide important information for the design of new inhibitors. 
Table 4. Toxicological profile of PTP1B inhibitors.

\begin{tabular}{|c|c|c|c|c|c|c|c|c|c|}
\hline Molecule & $\begin{array}{l}\mathrm{LD50}^{\mathrm{a}} \\
(\mathrm{mg} / \mathrm{kg})\end{array}$ & $\begin{array}{l}\text { Toxicity } \\
\text { Class }\end{array}$ & $\begin{array}{c}\text { Toxic } \\
\text { Frag. }{ }^{a}\end{array}$ & $\begin{array}{l}\text { Toxicity } \\
\text { Targets }^{\text {a }}\end{array}$ & Mutagenic $^{b}$ & Tumorigenic $^{b}$ & $\begin{array}{l}\text { Reprod. } \\
\text { Effec. }^{b}\end{array}$ & Irritant ${ }^{b}$ & $\begin{array}{c}\text { Drug } \\
\text { Likeness }\end{array}$ \\
\hline 1 & 1600 & 4 & None & No Binding & Low & None & High & High & 1.07 \\
\hline 2 & 1000 & 4 & None & No Binding & None & None & None & None & 0.86 \\
\hline 3 & 1600 & 4 & None & No Binding & Low & None & High & High & 0.66 \\
\hline
\end{tabular}

a Toxicity Class was determined in Server PROTOX [72], values ranged between 1 to 6, 1 is toxic and 6 is safe. Toxicity targets were determined for: Adenosine A2A receptor, Adrenergic beta 2 receptor, Androgen receptor, Amine oxidase, Dopamine D3 receptor, Estrogen receptor 1 and 2, Glucocorticoid receptor, Histamine H1 receptor, Nuclear receptor subfamily 1 group I member 2, Opioid receptor kappa, Opioid receptor mu, cAMP-specific $3^{\prime}, 5^{\prime}$-cyclic phosphodiesterase $4 \mathrm{D}$, Prostaglandin G/H synthase 1 , Progesterone receptor. ${ }^{\mathrm{b}}$ Mutagenic, Tumorigenic, Reproductive effective and Irritant effects were determined using Data Warrior [73]. ${ }^{\mathrm{c}}$ Drug-Likeness score was determined with Server Molsolf [45], values between -1 to 2 are accepted.

\section{Materials and Methods}

\subsection{General Information}

The reagents used were purchased from Sigma-Aldrich (St. Luis, CA USA), kinetic analysis were performed in a diode array spectrophotometer model 8453 from Agilent (Santa Clara, CA, USA).

\subsection{Compounds}

The tested chemical library was composed of an in-house set of 100 compounds and 150 small molecules of the Fragment Library and HitFinder ${ }^{\mathrm{TM}}$ collection from Maybridge (Waltham, MA, USA). Compounds 4 to 8 belong to Maybridge with the identification codes HTS 01664 for '1-(1,3-benzodioxol5-yl)-2-\{[1-(4-hydroxyphenyl)-1H-1,2,3,4-tetraazol-5-yl]sulfanyl\}-1-ethanone (4); SP 00892 for 4-\{5-[5-(3,5-dichlorophenoxy)-2-furyl]-1,2,4-oxadiazol-3-yl\}phenyl-N,N-dimethylsulfamate (5); RJF 01991 for ' $N^{\prime} 1-\{2-[(2-o x o-4-p r o p y l-2 H$-chromen-7-yl)oxy]propanoyl\}-3-(trifluoromethyl)benzene-1sulfonohydrazide (6); HTS 02534 for ' $N$-(3-chloro-4-fluorophenyl)-2-[(6,7-dimethoxy-4-oxo-3-phenyl3,4-dihydro-2-quinazolinyl)sulfanyl]acetamide (7); RH 02067 for ' $N$-\{3-[(3,5-difluorobenzyl)oxy]pyridin2-yl\}-4-pentylbenzenesulfonamide (8). The general synthesis method for compounds 1, 2, 3, 9 and 10 is outlined below.

Compounds 1-3 and 9 were prepared from the appropriate benzimidazole-2-amine and the adequate acid or anhydride under the guidelines of our synthetic procedure previously reported for similar benzimidazole derivatives [74,75]. Briefly, for compound 1: the substituted benzimidazol-2-amine was reacted with 5-chloro-1-methyl-2-(methylthio)-6-carboxylic acid, previously treated with $1,1^{\prime}$-carbonyldiimidazole in DMF at room temperature for $2 \mathrm{~h}$; then, the reaction mixture was heated at $140{ }^{\circ} \mathrm{C}$ under MW irradiation for $30 \mathrm{~min}$. For compounds 3 and 9: the substituted benzimidazol-2-amine was reacted with trifluoroacetic anhydride (compound 3) or acetic anhydride (compound 9) at $0{ }^{\circ} \mathrm{C}$ to r.t. in $\mathrm{CH}_{2} \mathrm{Cl}_{2}$ or $\mathrm{CHCl}_{3}$; compound 2 was prepared from 6-chloro-5-(1-naphtyloxy)-1H-benzimidazole-2-thiol [76] and 2-chloro- $N$-(thiazol-2-yl)acetamide in acetone at $0{ }^{\circ} \mathrm{C}$ [77]. Compound 10 was obtained as previously reported [78].

5-Chloro-N-[6-chloro-5-(2,3-dichlorophenoxy)-1H-benzimidazol-2-yl]-1-methyl-2-(methylthio)-1H-benz-imidazole6-carboxamide (1). Recrystallized from DMF/MeOH white solid (89\%); m.p. 269-270 ${ }^{\circ} \mathrm{C}$. ${ }^{1} \mathrm{H}-\mathrm{NMR}$ (DMSO-d $\left.d_{6} ; 00 \mathrm{MHz}\right): \delta 2.75\left(\mathrm{~s}, 3 \mathrm{H}, \mathrm{S}-\mathrm{CH}_{3}\right) ; 3.72$ (s, 3H, N-CH$) ; 6.69$ (dd, 1H, J = 8.2 Hz, $1.2 \mathrm{~Hz}$, H-6 dichlorophenoxy); 7.27 (t, 1H, J = 8.2 Hz, H-5 dichlorophenoxy); 7.33 (s, 1H, H-4'); 7.37 (dd, $1 \mathrm{H}, J=8.4 \mathrm{~Hz}, 1.2 \mathrm{~Hz}, \mathrm{H}-4$ dichlorophenoxy); 7.68 (s, 1H, H-7'); 7.71 (s, 1H, H-5); 7.91 (s, 1H, H-7); 12.40 (bs, $1 \mathrm{H}, \mathrm{NH}$, int. $\left.\mathrm{D}_{2} \mathrm{O}\right) .{ }^{13} \mathrm{C}-\mathrm{NMR}\left(\mathrm{DMSO}-d_{6} ; 100 \mathrm{MHz}\right): \delta 14.48\left(\mathrm{~S}^{-\mathrm{CH}_{3}}\right) ; 30.56\left(\mathrm{~N}-\underline{C H}_{3}\right)$; 110.93 (C-7 benzimidazole); 115.64 (C-6 dichlorophenoxy); 118.45 (C-4 benzimidazole); 118.59 (C-7'a benz-imidazole); 121.36 (C-2 dichlorophenoxy); 123.73 (C-5 benzimidazole); 124.69 (C-4 dichlorophenoxy); 127.79 C-6 benzimidazole); 129.11 (C-5 dichlorophenoxy); 133.23 (C-3 dichlorophenoxy); 135.63 (C-7a benzimidazole); 144.89 (C-3a benzimidazole); 145.04 (C-6' benzimidazole); 148.58 (C-2' benzimidazole); 155.10 (C-1 dichlorophenoxy); 157.27 (C-2 
benzimidazole); 166.85 ( $\underline{C}=\mathrm{O}$ amide). EI-MS: $m / z 565\left(\mathrm{M}^{+}\right)$; HRMS $\left(\mathrm{FAB}^{+}\right): 565.9752[\mathrm{M}+\mathrm{H}]^{+}(\mathrm{Calcd}$ for $\mathrm{C}_{23} \mathrm{H}_{15} \mathrm{O}_{2} \mathrm{~N}_{5} \mathrm{Cl}_{4} \mathrm{SH}^{+}$565.9773).

2-[6-Chloro-5-(1-naphthalyloxy)-1H-benzimidazol-2-yl]thio-N-(thiazol-2-yl)acetamide (2). Recrystallized from methanol to give a beige solid (20\% yield); m.p. $155-157^{\circ} \mathrm{C} .{ }^{1} \mathrm{H}-\mathrm{NMR}(400 \mathrm{MHz}, \mathrm{DMSO}): \delta 4.37$ $\left(\mathrm{s}, 2 \mathrm{H},-\mathrm{CH}_{2}-\right) .6 .64(\mathrm{~d}, J=7.6 \mathrm{~Hz}, 1 \mathrm{H}, \mathrm{H}-2$ naphtyloxy), $7.23(\mathrm{~d}, J=3.6 \mathrm{~Hz}, 1 \mathrm{H}, \mathrm{H}-5$ thiazolyl), $7.27(\mathrm{~s}, 1 \mathrm{H}$, $\mathrm{H}-7), 7.37(\mathrm{t}, J=8.0 \mathrm{~Hz}, 1 \mathrm{H}, \mathrm{H}-3$ naphtyloxy), $7.48(\mathrm{~d}, J=3.6 \mathrm{~Hz}, 1 \mathrm{H}, \mathrm{H}-4$ thiazolyl), 7.61-7.57 (m, 2H, H-6 y H-7 naphtyloxy), 7.64 (d, J = 8.0 Hz, 1H, H-4 naphtyloxy), 7.72 (s, 1H, H-4), 7.99-7.95 (m, 1H, H-5 naphtyloxy), 8.27-8.22 (m, 1H, H-8 naphtyloxy), $\delta 12.70$ (s, 1H, CONH). ${ }^{13} \mathrm{C}-\mathrm{NMR}$ (DMSO- $d_{6}$; $100 \mathrm{MHz}): \delta 34.79\left(\mathrm{SCH}_{2}\right), 109.88$ (C-2 naphtyloxy), 113.78 (C-3 naphtyloxy), 119.12 (C-5 thiazolyl), 121.36 (C-8 naphtyloxy), 122.45 (C-4 naphtyloxy), 124.86 (C-5 or C-6), 126.02 (C-6 or C-7 naphtyloxy), 126.13 (C-6 or C-7 naphtyloxy), 126.85 (C-4a or C-8a naphtyloxy), 127.77 (C-5 naphtyloxy), 134.45 (C-4a or C-8a naphtyloxy), 137.76 (C-4 thiazolyl), 146.06 (C-3a or C-7a), 151.96 (C-3a or C-7a), 153.37 (C-2), 157.81 (C-2 thiazolyl), 166.22 (CONH). MS (DART): $m / z(\%): 467\left([\mathrm{M}+\mathrm{H}]^{+}, 15\right)$. HRMS (DART): Calcd for $\mathrm{C}_{22} \mathrm{H}_{15} \mathrm{ClN}_{4} \mathrm{O}_{2} \mathrm{~S}_{2}[\mathrm{M}+\mathrm{H}]^{+}: 467.04032$, found: 467.04177 .

N-[6-Chloro-5-(2,3-dichlorophenoxy)-1H-benzimidazol-2-yl]-2,2,2-trifluoroacetamide (3). Purified by washing with cold water. Beige solid; m.p. $>200{ }^{\circ} \mathrm{C}$ (d). ${ }^{1} \mathrm{H}-\mathrm{NMR}(400 \mathrm{MHz}, \mathrm{DMSO}) \delta: 6.84\left(\mathrm{dd}, 1 \mathrm{H}, J_{1}=8.3\right.$, $\left.J_{2}=1.3 \mathrm{~Hz}, \mathrm{H}-6^{\prime}\right) ; 7.21(\mathrm{~s}, 1 \mathrm{H}, \mathrm{H}-4) ; 7.32\left(\mathrm{t}, 1 \mathrm{H}, J=8.2 \mathrm{~Hz}, \mathrm{H}-5^{\prime}\right) ; 7.44\left(\mathrm{dd}, 1 \mathrm{H}, J_{1}=8.1 \mathrm{~Hz}, J_{2}=1.3 \mathrm{~Hz}\right.$, $\left.\mathrm{H}-4^{\prime}\right) ; 7.66$ (s, 1H, H-7); 13.07 (bs, 1H, CO-N $\underline{H}$ ). ${ }^{13} \mathrm{C}-\mathrm{NMR}$ (DMSO-d $d_{6} ; 100 \mathrm{MHz}$ ): $\delta 105.22$ (C-4), 114.10 $(\mathrm{C}-7), 116.97\left(\mathrm{C}-6^{\prime}\right), 117.52\left(\mathrm{q}, J_{\mathrm{F}-\mathrm{C}}=287 \mathrm{~Hz},-\underline{\mathrm{CF}}_{3}\right), 120.37(\mathrm{C}-6), 122.15\left(\mathrm{C}-2^{\prime}\right), 125.65\left(\mathrm{C}-4^{\prime}\right), 127.03$, 129.22, $129.36\left(\mathrm{C}-5^{\prime}\right), 133.41\left(\mathrm{C}-3^{\prime}\right), 147.07(\mathrm{C}-5), 153.98(\mathrm{C}-2), 154.17\left(\mathrm{C}-1^{\prime}\right), 162.99\left(\mathrm{q}, \mathrm{J}_{\mathrm{F}-\mathrm{C}}=35 \mathrm{~Hz}, \underline{\mathrm{CO}}\right)$.

$\mathrm{N}$-[6-Chloro-5-(2,3-dichlorophenoxy)-1-methyl-1H-benzimidazol-2-yl]acetamide (9). Recrystallized from ethanol, white crystals (84\% yield); m.p. 237.5-238.9 ${ }^{\circ} \mathrm{C} .{ }^{1} \mathrm{H}-\mathrm{NMR}(400 \mathrm{MHz}, \mathrm{DMSO}) \delta: 2.16(\mathrm{~s}, 3 \mathrm{H}$, $\left.\mathrm{CO}-\mathrm{CH}_{3}\right) ; 3.64\left(\mathrm{~s}, 1 \mathrm{H}, \mathrm{N}-\mathrm{CH}_{3}\right) ; 6.65\left(\mathrm{~d}, 1 \mathrm{H}, J_{1}=8.2 \mathrm{~Hz}, J_{2}=0.9 \mathrm{~Hz}, \mathrm{H}-6^{\prime}\right) ; 7.24\left(\mathrm{t}, 1 \mathrm{H}, J=8.2 \mathrm{~Hz}, \mathrm{H}-5^{\prime}\right)$; $7.36\left(\mathrm{dd}, 1 \mathrm{H}, J_{1}=8.1 \mathrm{~Hz}, J_{2}=1.3 \mathrm{~Hz}, \mathrm{H}-4^{\prime}\right) ; 7.42$ (s, 1H, H-4); 7.88 (s, 1H, H-7); 10.97 (bs, 1H, CO-NH). ${ }^{13} \mathrm{C}-\mathrm{NMR}$ (DMSO- $\left.d_{6} ; 100 \mathrm{MHz}\right): \delta 23.43\left(\mathrm{CO}-\mathrm{CH}_{3}\right), 30.97\left(\mathrm{~N}-\mathrm{CH}_{3}\right), 111.95$ (C-4), 112.27 (C-7), 115.51 (C-6'), 119.52 (C-6), $121.28\left(\mathrm{C}-2^{\prime}\right), 124.70\left(\mathrm{C}-4^{\prime}\right), 129.16\left(\mathrm{C}-5^{\prime}\right), 133.25,140.41\left(\mathrm{C}-3^{\prime}\right), 145.39$ (C-4), 148.37 (C-2), $155.14\left(\mathrm{C}-1^{\prime}\right), 170.57$ (ㄷ) $)$. EA. Calc.: $\mathrm{C}_{16} \mathrm{H}_{12} \mathrm{Cl}_{3} \mathrm{~N}_{3} \mathrm{O}_{2}$ : C, 49.96; $\mathrm{H}, 3.14 ; \mathrm{N}$, 10.9. Found: $\mathrm{C}, 49.82$; $\mathrm{H}, 2.57 ; \mathrm{N}, 10.6$. HMRS (ESI) Calcd for $\mathrm{C}_{16} \mathrm{H}_{12} \mathrm{Cl}_{3} \mathrm{~N}_{3} \mathrm{O}_{2}$ [M + Na]: 406.0073; found 406 .

\subsection{Expression and Purification of PTP1B}

The region of the gene PTPN1 that encodes for PTP1B (residues 1-321) was synthetized by Integrated DNA Technologies and inserted in the pIDTSmart plasmid. Then, the gene was liberated by restriction reactions using Ndel and BamH1 enzymes and inserted into the overexpression vector pET28A. Afterwards, E. coli BLR strains were transformed for the overexpression of the protein. With this purpose, $500 \mathrm{~mL}$ of LB liquid culture medium was grown supplemented with Kanamycin $(50 \mu \mathrm{g} / \mathrm{mL})$ at $37^{\circ} \mathrm{C}$, once it reached an optical density of 0.9 at $600 \mathrm{~nm}, 1 \mathrm{mM}$ of IPTG was added to induce the overexpression, incubating four more hours. Right away, cells were cultured by centrifugation and lysed by sonication. The supernatant was passed through a Ni-agarose column and the enzyme was purified by an imidazole gradient. The fractions were analyzed by SDS-PAGE electrophoresis and those with the presence of the protein were pooled and concentrated with a Plus-70 centricon, immediately the enzyme was precipitated with ammonium sulfate (80\% saturation).

\subsection{Enzymatic Activity}

The PTP1B activity was measured based on the Goldstein method [79]. The assay was performed with a final reaction volume of $500 \mu \mathrm{L}$ in HEPES buffer (50 mM HEPES, 1mM DTT, 2 mM EDTA and $150 \mathrm{mM} \mathrm{NaCl}, \mathrm{pH} 7.0)$, DMSO (10\%) and p-nitrophenol phosphate (pNPP) as substrate $(50 \mathrm{mM})$, the reaction was started with the PTP1B $(1.5 \mu \mathrm{g} / \mathrm{mL})$. After $30 \mathrm{~min}$ of incubation at $37^{\circ} \mathrm{C}$, the reaction 
was stopped by the addition of $500 \mu \mathrm{L}$ of $\mathrm{NaOH} 5 \mathrm{~N}$ reading the absorbance at $405 \mathrm{~nm}$. The number of hydrolyzed moles of $\mathrm{pNPP}$ was determined using the molar extinction coefficient of the product $\mathrm{pNP}$ $\left(18,500 \mathrm{M}^{-1} \mathrm{~cm}^{-1}\right)$.

\subsection{Inhibition Assays}

Inhibition assays were performed under the above described conditions, adding to the reaction each one of the molecules at a final concentration of $200 \mu \mathrm{M}$. The concentration that inhibits $50 \%\left(\mathrm{IC}_{50}\right)$ of the PTP1B activity was determined through curves at different concentration of each compound, adjusting the data to the equation reported elsewhere [80]. The inhibition type and constant were obtained by the measurement of the initial velocities of hydrolysis varying the substrate concentration in a range of 2-30 $\mathrm{MM}$, in absence or presence of fixed concentrations of each inhibitor. For compound 1 the concentrations used were $3,6,10$ and $20 \mu \mathrm{M}$; in the case of compound 2 were 2, 4, 6, 8, and $10 \mu \mathrm{M}$; and for compound 3 were 20,50, 70 and $90 \mu \mathrm{M}$. The experimental data were analyzed through the Lineweaver-Burk plot using the software Sigma Plot V12.3 (Systat Software, Inc., San Jose, CA, USA).

\subsection{Molecular Docking}

The molecules were built in Maestro 10.4 (www.schrodinger.com) and prepared in Ligprep 2.3 [81]. The crystallographic structure of the PTP1B protein was obtained from the RCSB Protein Data Bank with the code PDB ID 2F71 [64]. Hydrogen atoms were added to the structure, bond angles, and distances were corrected, and charges were assigned using Protein Preparation Wizard [82], all ions and the inhibitor present in the crystallographic structure were withdrawn. Water molecules were also withdrawn, with exception of those located in the WPD loop, since these are considered necessary to give better binding poses [83]. Energy minimization was performed with the OPLS_2005 force field with an RMSD of $0.3 \AA$. The molecular docking simulations in the active site of the PTP1B were performed using Glide [84,85]. The Van der Waals scale was of a factor of 0.80 and a cutting partial charge of 0.15 . The files were limited to at least one pose for ligand, rejecting poses with energies smaller than $0.5 \mathrm{kcal} / \mathrm{mol}$. Standard precision and Extra precision modes were used with flexible ligand adding penalization states of the Epik software [86] in the docking score.

\subsection{Molecular Dynamic Simulations}

The initial structures for the simulations were those with the lowest binding energy of each complex obtained by docking. The necessary topology files for each ligand (compounds 1, 2 and 3) were calculated and obtained using PRODRG [87]. The systems were solvated within a water box with $1.0 \mathrm{~nm}$ of distance from the proteins surface with the Single Point Charge (SPC) water model. Sodium and Chlorine ions were added to neutralize the systems charge until a $0.15 \mathrm{M}$ concentration was reached. First, a descending steps energy minimization was done. Afterwards, a canonic assemble was performed, continuing by an isobaric-isothermal assemble, maintaining a constant temperature, volume and pressure. Finally, 10 ns simulations were performed for each complex and the free enzyme in GROMACS 5.1 software [88] using the Gromos 43 a147 force field. All simulations were performed at 1 bar of pressure and $300^{\circ} \mathrm{K}$ of temperature. The free binding energy was calculated based on the molecular mechanics of surface area of Poisson-Boltzmann (MM-PBSA) method [89].

\subsection{Drug-Like and Toxicological Propierties}

The FAF-Drugs4 server [42] and the Molsoft [45] program, available on the web were used. The Drug-like soft filter used in FAF-Drugs4 combines the physicochemical properties described in several articles and an analysis of the descriptor values of 916 oral medications of the FDA, allowing defining a filter threshold that comprises up to $90 \%$ of these drugs. The ranges of the permitted values used by the software are shown in Table 1. Regarding Molsoft, it uses the fingerprints technique with a set of 5000 commercialized drugs and 10,000 non-pharmacological compounds. After the process, it reports a score that places the molecules in a range between the parameters of the drugs 
and the non-drugs, which allows defining their pharmacological potential; values between -1 to 2 are accepted.

With respect to toxicological parameters, PROTOX [72] server was used, as well the Data Warrior software [73] to determine mutagenesis, tumorigenic, reproductive effects and irritability. PROTOX uses the identification of fragments over-represented in toxic compounds and similarity analyses of compounds with known LD50 values. Furthermore, based on pharmacophores, it indicates possible toxicity targets. Data Warrior uses chemical descriptors to make several molecular similarity measures and predict properties such as mutagenicity, tumorigenicity, irritant and reproductive effects.

\section{Conclusions}

In the present work three new mixed type inhibitors for PTP1B are reported, which based on their inhibition capability and mechanism, potential selectivity against TCPTP, and predicted drug-like properties, could represent a good starting point for the development of more potent molecules that can guide the design of a new drug to treat type 2 diabetes.

Supplementary Materials: Supplementary materials are available online.

Acknowledgments: Access to the Maybridge Fragment Library collection kindly provided by Armando Gómez-Puyou is highly appreciated. ATV and CAD acknowledge CONACyT for grants No. 257848 and No. 258694, respectively. RC and AHC acknowledge to CONACyT for finatial support of project No. 251726 and DGAPA-PAPIIT, UNAM for project No. IN221416. CONACyT is also acknowledged for the fellowship granted to MSS (No. 271541), PJTS (No. 409406/No. 258048), and JMVL (No. 225078). We thank Rosa Isela del Villar Morales and Nayeli López Baliaux for the determination of NMR spectra.

Author Contributions: Performed the experiments: M.J.S.-S., P.J.T.-S., J.M.V.-L., and C.C.-G. Conceived and designed in-house compounds library: R.C. and A.H.-C. Conceived, designed the experiments and contributed reagents/materials/analysis tools: R.C., A.H.-C., C.A.-D., E.S.-C., J.M.S.-P., and A.T.-V. Analyzed the data and wrote the paper: M.S.-S., D.E.-M., C.A.-D., E.S.-C., M.V.-S., and A.T.-V.

Conflicts of Interest: The authors declare no conflict of interest.

\section{References}

1. International Diabetes Federation. IDF Diabetes Atlas, 2nd ed.; International Diabetes Federation: Brussels, Belgium, 2003.

2. International Diabetes Federation. IDF Diabetes Atlas, 6th ed.; International Diabetes Federation: Brussels, Belgium, 2014.

3. Bujaidar, E.M.; Juárez, N.G. Revisión de las caracteristicas clinicas, metabólicas y genéticas de la diabetes mellitus. Bioquimia 2003, 28, 14-23.

4. Gershell, L. Type 2 diabetes market. Nat. Rev. Drug Discov. 2005, 4, 367-368. [CrossRef] [PubMed]

5. Shinde, R.N.; Sobhia, M.E. Binding and discerning interactions of PTP1B allosteric inhibitors: Novel insights from molecular dynamics simulations. J. Mol. Graph. Model. 2013, 45, 98-110. [CrossRef] [PubMed]

6. Di Paola, R.; Frittitta, L.; Miscio, G.; Bozzali, M.; Baratta, R.; Centra, M.; Spampinato, D.; Santagati, M.G.; Ercolino, T.; Cisternino, C.; et al. A variation in $3^{\prime}$ UTR of hPTP1B increases specific gene expression and associates with insulin resistance. Am. J. Hum. Genet. 2002, 70, 806-812. [CrossRef] [PubMed]

7. Bento, J.L.; Palmer, N.D.; Mychaleckyj, J.C.; Lange, L.A.; Langefeld, C.D.; Rich, S.S.; Freedman, B.I.; Bowden, D.W. Association of protein tyrosine phosphatase 1B gene polymorphisms with type 2 diabetes. Diabetes 2004, 53, 3007-3012. [CrossRef] [PubMed]

8. Asante-Appiah, E.; Kennedy, B.P. Protein tyrosine phosphatases: the quest for negative regulators of insulin action. Am. J. Physiol. Endocrinol. Metab. 2003, 284, E663-E670. [CrossRef] [PubMed]

9. Cho, H. Protein Tyrosine Phosphatase 1B (PTP1B) and Obesity, 1st ed.; Elsevier Inc.: Amsterdam, The Netherlands, 2013; Volume 91.

10. Bakke, J.; Bettaieb, A.; Nagata, N.; Matsuo, K.; Haj, F.G. Regulation of the SNARE-interacting protein Munc18c tyrosine phosphorylation in adipocytes by protein-tyrosine phosphatase 1B. Cell Commun. Signal. 2013, 11, 57. [CrossRef] [PubMed] 
11. Elchebly, M.; Payette, P.; Michaliszyn, E.; Cromlish, W.; Collins, S.; Loy, A.L.; Normandin, D.; Cheng, A.; Himms-Hagen, J.; Chan, C.C.; et al. Increased insulin sensitivity and obesity resistance in mice lacking the protein tyrosine phosphatase-1B gene. Science 1999, 283, 1544-1548. [CrossRef] [PubMed]

12. Klaman, L.D.; Boss, O.; Peroni, O.D.; Kim, J.K.; Martino, J.L.; Zabolotny, J.M.; Moghal, N.; Lubkin, M.; Kim, Y.B.; Sharpe, A.H.; et al. Increased energy expenditure, decreased adiposity, and tissue-specific insulin sensitivity in protein-tyrosine phosphatase 1B-deficient mice. Mol. Cell. Biol. 2000, 20, 5479-5489. [CrossRef] [PubMed]

13. Kushner, J.A.; Haj, F.G.; Klaman, L.D.; Dow, M.A.; Kahn, B.B.; Neel, B.G.; White, M.F. Islet-sparing effects of protein tyrosine phosphatase-1b deficiency delays onset of diabetes in IRS2 knockout mice. Diabetes 2004, 53, 61-66. [CrossRef] [PubMed]

14. He, R.; Zeng, L.F.; He, Y.; Zhang, S.; Zhang, Z.Y. Small molecule tools for functional interrogation of protein tyrosine phosphatases. FEBS J. 2013, 280, 731-750. [CrossRef] [PubMed]

15. Tamrakar, A.K.; Maurya, C.K.; Rai, A.K. PTP1B inhibitors for type 2 diabetes treatment: A patent review (2011-2014). Expert Opin. Ther. Pat. 2014, 24, 1101-1115. [CrossRef] [PubMed]

16. Zhou, Y.; Zhang, W.; Liu, X.; Yu, H.; Lu, X.; Jiao, B. Inhibitors of Protein Tyrosine Phosphatase 1B from Marine Natural Products. Chem. Biodivers. 2017, 14, e1600462. [CrossRef] [PubMed]

17. Jiang, C.-S.; Liang, L.; Guo, Y. Natural products possessing protein tyrosine phosphatase 1B (PTP1B) inhibitory activity found in the last decades. Acta Pharmacol. Sin. 2012, 33, 1217-1245. [CrossRef] [PubMed]

18. Bharatam, P.V.; Patel, D.S.; Adane, L.; Mittal, A.; Sundriyal, S. Modeling and informatics in designing anti-diabetic agents. Curr. Pharm. Des. 2007, 13, 3518-3530. [CrossRef] [PubMed]

19. Combs, A.P. Recent advances in the discovery of competitive protein tyrosine phosphatase 1B inhibitors for the treatment of diabetes, obesity, and cancer. J. Med. Chem. 2010, 53, 2333-2344. [CrossRef] [PubMed]

20. Popov, D. Novel protein tyrosine phosphatase 1B inhibitors: Interaction requirements for improved intracellular efficacy in type 2 diabetes mellitus and obesity control. Biochem. Biophys. Res. Commun. 2011, 410, 377-381. [CrossRef] [PubMed]

21. Adams, D.R.; Abraham, A.; Asano, J.; Breslin, C.; Dick, C.A.J.; Ixkes, U.; Johnston, B.F.; Johnston, D.; Kewnay, J.; Mackay, S.P.; et al. 2-Aryl-3,3,3-trifluoro-2-hydroxypropionic acids: A new class of protein tyrosine phosphatase 1B inhibitors. Bioorg. Med. Chem. Lett. 2007, 17, 6579-6583. [CrossRef] [PubMed]

22. Zhao, H.; Liu, G.; Xin, Z.; Serby, M.D.; Pei, Z.; Szczepankiewicz, B.G.; Hajduk, P.J.; Abad-Zapatero, C.; Hutchins, C.W.; Lubben, T.H.; et al. Isoxazole carboxylic acids as protein tyrosine phosphatase 1B (PTP1B) inhibitors. Bioorg. Med. Chem. Lett. 2004, 14, 5543-5546. [CrossRef] [PubMed]

23. Black, E.; Breed, J.; Breeze, A.L.; Embrey, K.; Garcia, R.; Gero, T.W.; Godfrey, L.; Kenny, P.W.; Morley, A.D.; Minshull, C.A.; et al. Structure-based design of protein tyrosine phosphatase-1B inhibitors. Bioorg. Med. Chem. Lett. 2005, 15, 2503-2507. [CrossRef] [PubMed]

24. Douty, B.; Wayland, B.; Ala, P.J.; Bower, M.J.; Pruitt, J.; Bostrom, L.; Wei, M.; Klabe, R.; Gonneville, L.; Wynn, R.; et al. Isothiazolidinone inhibitors of PTP1B containing imidazoles and imidazolines. Bioorg. Med. Chem. Lett. 2008, 18, 66-71. [CrossRef] [PubMed]

25. Shrestha, S.; Bhattarai, B.R.; Lee, K.H.; Cho, H. Mono- and disalicylic acid derivatives: PTP1B inhibitors as potential anti-obesity drugs. Bioorg. Med. Chem. 2007, 15, 6535-6548. [CrossRef] [PubMed]

26. Akamatsu, M.; Roller, P.P.; Chen, L.; Zhang, Z.Y.; Ye, B.; Burke, T.R. Potent inhibition of protein-tyrosine phosphatase by phosphotyrosine-mimic containing cyclic peptides. Bioorg. Med. Chem. 1997, 5, 157-163. [CrossRef]

27. Burke, T.R.; Yao, Z.J.; Zhao, H.; Milne, G.W.A.; Wu, L.; Zhang, Z.Y.; Voigt, J.H. Enantioselective synthesis of nonphosphorus-containing phosphotyrosyl mimetics and their use in the preparation of tyrosine phosphatase inhibitory peptides. Tetrahedron 1998, 54, 9981-9994. [CrossRef]

28. Wilson, D.P.; Wan, Z.K.; Xu, W.X.; Kirincich, S.J.; Follows, B.C.; Joseph-McCarthy, D.; Foreman, K.; Moretto, A.; $\mathrm{Wu}$, J.; $\mathrm{Zhu}, \mathrm{M} . ;$ the active site to the second phosphotyrosine binding site. J. Med. Chem. 2007, 50, 4681-4698. [CrossRef] [PubMed]

29. Combs, A.P.; Yue, E.W.; Bower, M.; Ala, P.J.; Wayland, B.; Douty, B.; Takvorian, A.; Polam, P.; Wasserman, Z.; $\mathrm{Zhu}, \mathrm{W}$; ; et al. Structure-based design and discovery of protein tyrosine phosphatase inhibitors incorporating novel isothiazolidinone heterocyclic phosphotyrosine mimetics. J. Med. Chem. 2005, 48, 6544-6548. [CrossRef] [PubMed] 
30. Ye, D.; Zhang, Y.; Wang, F.; Zheng, M.; Zhang, X.; Luo, X.; Shen, X.; Jiang, H.; Liu, H. Novel thiophene derivatives as PTP1B inhibitors with selectivity and cellular activity. Bioorg. Med. Chem. 2010, 18, 1773-1782. [CrossRef] [PubMed]

31. Liu, Z.; Lee, W.; Kim, S.-N.; Yoon, G.; Cheon, S.H. Design, synthesis, and evaluation of bromo-retrochalcone derivatives as protein tyrosine phosphatase 1B inhibitors. Bioorg. Med. Chem. Lett. 2011, 21, 3755-3758. [CrossRef] [PubMed]

32. Seo, C.; Choi, Y.H.; Sohn, J.H.; Ahn, J.S.; Yim, J.H.; Lee, H.K.; Oh, H. Ohioensins F and G: Protein tyrosine phosphatase $1 \mathrm{~B}$ inhibitory benzonaphthoxanthenones from the Antarctic moss polytrichastrum alpinum. Bioorg. Med. Chem. Lett. 2008, 18, 772-775. [CrossRef] [PubMed]

33. Iversen, L.F.; Møller, K.B.; Pedersen, A.K.; Peters, G.H.; Petersen, A.S.; Andersen, H.S.; Branner, S.; Mortensen, S.B.; Møller, N.P.H. Structure determination of T cell protein-tyrosine phosphatase. J. Biol. Chem. 2002, 277, 19982-19990. [CrossRef] [PubMed]

34. Andersen, J.N.; Mortensen, O.H.; Peters, G.H.; Drake, P.G.; Iversen, L.F.; Olsen, O.H.; Peter, G.; Andersen, H.S.; Tonks, N.K.; Møller, P.H.; et al. Structural and Evolutionary Relationships among Protein Tyrosine Phosphatase Domains Structural and Evolutionary Relationships among Protein Tyrosine Phosphatase Domains. Mol. Cell. Biol. 2001, 21, 7117-7136. [CrossRef] [PubMed]

35. Li, X.Q.; Wang, L.J.; Shi, D.Y. The design strategy of selective PTP1B inhibitors over TCPTP. Bioorg. Med. Chem. 2016, 24, 3343-3352. [CrossRef] [PubMed]

36. Du, Y.; Ling, H.; Zhang, M.; Shen, J.; Li, Q. Discovery of novel, potent, selective and cellular active ADC type PTP1B inhibitors via fragment-docking-oriented de novel design. Bioorg. Med. Chem. 2015, 23, 4891-4898. [CrossRef] [PubMed]

37. Liu, P.; Du, Y.; Song, L.; Shen, J.; Li, Q. Novel, potent, selective and cellular active ABC type PTP1B inhibitors containing (methanesulfonyl-phenyl-amino)-acetic acid methyl ester phosphotyrosine mimetic. Bioorg. Med. Chem. 2015, 23, 7079-7088. [CrossRef] [PubMed]

38. Lantz, K.A.; Hart, S.G.E.; Planey, S.L.; Roitman, M.F.; Ruiz-White, I.A.; Wolfe, H.R.; McLane, M.P. Inhibition of PTP1B by trodusquemine (MSI-1436) causes fat-specific weight loss in diet-induced obese mice. Obesity 2010, 18, 1516-1523. [CrossRef] [PubMed]

39. Liu, J.Z.; Zhang, S.E.; Nie, F.; Yang, Y.; Tang, Y.B.; Yin, W.; Tian, J.Y.; Ye, F.; Xiao, Z. Discovery of novel PTP1B inhibitors via pharmacophore-oriented scaffold hopping from Ertiprotafib. Bioorg. Med. Chem. Lett. 2013, 23, 6217-6222. [CrossRef] [PubMed]

40. Swarbrick, M.M.; Havel, P.J.; Levin, A.A.; Bremer, A.A.; Stanhope, K.L.; Butler, M.; Booten, S.L.; Graham, J.L.; McKay, R.A.; Murray, S.F.; et al. Inhibition of protein tyrosine phosphatase-1B with antisense oligonucleotides improves insulin sensitivity and increases adiponectin concentrations in monkeys. Endocrinology 2009, 150, 1670-1679. [CrossRef] [PubMed]

41. Ala, P.J.; Gonneville, L.; Hillman, M.; Becker-Pasha, M.; Yue, E.W.; Douty, B.; Wayland, B.; Polam, P.; Crawley, M.L.; McLaughlin, E.; et al. Structural insights into the design of nonpeptidic isothiazolidinone-containing inhibitors of protein-tyrosine phosphatase 1B. J. Biol. Chem. 2006, 281, 38013-38021. [CrossRef] [PubMed]

42. Combs, A.P.; Zhu, W.; Crawley, M.L.; Glass, B.; Polam, P.; Sparks, R.B.; Modi, D.; Takvorian, A.; McLaughlin, E.; Yue, E.W.; et al. Potent benzimidazole sulfonamide protein tyrosine phosphatase 1B inhibitors containing the heterocyclic (S)-isothiazolidinone phosphotyrosine mimetic. J. Med. Chem. 2006, 49, 3774-3789. [CrossRef] [PubMed]

43. Sparks, R.B.; Polam, P.; Zhu, W.; Crawley, M.L.; Takvorian, A.; McLaughlin, E.; Wei, M.; Ala, P.J.; Gonneville, L.; Taylor, N.; et al. Benzothiazole benzimidazole (S)-isothiazolidinone derivatives as protein tyrosine phosphatase-1B inhibitors. Bioorg. Med. Chem. Lett. 2007, 17, 736-740. [CrossRef] [PubMed]

44. Lagorce, D.; Sperandio, O.; Galons, H.; Miteva, M.A.; Villoutreix, B.O. FAF-Drugs2: Free ADME/tox filtering tool to assist drug discovery and chemical biology projects. BMC Bioinform. 2008, 9, 396. [CrossRef] [PubMed]

45. Molsoft. Available online: http://molsoft.com/mprop/ (accessed on 5 June 2017).

46. Segel, I.H. Enzyme Kinetics: Behavior and Analysis of Rapid Equilibrium and Steady-State Enzyme Systems; John Wiley Sons: New York, NY, USA, 1993.

47. Cheng, Y.; Prusoff, W.H. Relationship between the inhibition constant (K1) and the concentration of inhibitor which causes 50 per cent inhibition (I50) of an enzymatic reaction. Biochem. Pharmacol. 1973, 22, 3099-3108. [PubMed] 
48. EMBL-EBI The European Bioinformatics Institute. Available online: http://www.ebi.ac.uk/ (accessed on 7 December 2017).

49. Haftchenary, S.; Ball, D.P.; Aubry, I.; Landry, M.; Shahani, V.M.; Fletcher, S.; Page, B.D.G.; Jouk, A.O.; Tremblay, M.L.; Gunning, P.T. Identification of a potent salicylic acid-based inhibitor of tyrosine phosphatase PTP1B. Med. Chem. Commun. 2013, 4, 987-992. [CrossRef]

50. Raj, B.; Kafle, B.; Hwang, J.; Wook, S.; Lee, K.; Park, H.; Han, I.; Cho, H. Novel thiazolidinedione derivatives with anti-obesity effects: Dual action as PTP1B inhibitors and PPAR activators. Bioorg. Med. Chem. Lett. 2010, 20, 6758-6763. [CrossRef]

51. Cheung, A.W.; Banner, B.; Bose, J.; Kim, K.; Li, S.; Marcopulos, N.; Orzechowski, L.; Sergi, J.A.; Thakkar, K.C.; Wang, B.; et al. 7-Phenyl-pyrido[2,3-d]pyrimidine-2,4-diamines: Novel and highly selective protein tyrosine phosphatase 1B inhibitors. Bioorg. Med. Chem. Lett. 2012, 22, 7518-7522. [CrossRef] [PubMed]

52. Ramírez-Espinosa, J.J.; Rios, M.Y.; López-Martínez, S.; López-Vallejo, F.; Medina-Franco, J.L.; Paoli, P.; Camici, G.; Navarrete-Vázquez, G.; Ortiz-Andrade, R.; Estrada-Soto, S. Antidiabetic activity of some pentacyclic acid triterpenoids, role of PTP-1B: In vitro, in silico, and in vivo approaches. Eur. J. Med. Chem. 2011, 46, 2243-2251. [CrossRef] [PubMed]

53. Li, Y.; Yu, Y.; Jin, K.; Gao, L.; Luo, T.; Sheng, L.; Shao, X.; Li, J. Synthesis and biological evaluation of novel thiadiazole amides as potent Cdc25B and PTP1B inhibitors. Bioorg. Med. Chem. Lett. 2014, 24, 4125-4128. [CrossRef] [PubMed]

54. Li, W.; Li, S.; Higai, K.; Sasaki, T.; Asada, Y.; Ohshima, S.; Koike, K. Evaluation of licorice flavonoids as protein tyrosine phosphatase 1B inhibitors. Bioorg. Med. Chem. Lett. 2013, 23, 5836-5839. [CrossRef] [PubMed]

55. Navarrete-Vazquez, G.; Paoli, P.; León-Rivera, I.; Villalobos-Molina, R.; Medina-Franco, J.L.; Ortiz-Andrade, R.; Estrada-Soto, S.; Camici, G.; Diaz-Coutiño, D.; Gallardo-Ortiz, I.; et al. Synthesis, in vitro and computational studies of protein tyrosine phosphatase $1 \mathrm{~B}$ inhibition of a small library of 2-arylsulfonylaminobenzothiazoles with antihyperglycemic activity. Bioorg. Med. Chem. 2009, 17, 3332-3341. [CrossRef] [PubMed]

56. Navarrete-Vazquez, G.; Ramírez-Martínez, M.; Estrada-Soto, S.; Nava-Zuazo, C.; Paoli, P.; Camici, G.; Escalante-García, J.; Medina-Franco, J.L.; López-Vallejo, F.; Ortiz-Andrade, R. Synthesis, in vitro and in silico screening of ethyl 2-(6-substituted benzo[d]thiazol-2-ylamino)-2-oxoacetates as protein-tyrosine phosphatase 1B inhibitors. Eur. J. Med. Chem. 2012, 53, 346-355. [CrossRef] [PubMed]

57. Ottanà, R.; Maccari, R.; Mortier, J.; Caselli, A.; Amuso, S.; Camici, G.; Rotondo, A.; Wolber, G.; Paoli, P. Synthesis, biological activity and structure-activity relationships of new benzoic acid-based protein tyrosine phosphatase inhibitors endowed with insulinomimetic effects in mouse C2C12 skeletal muscle cells. Eur. J. Med. Chem. 2014, 71, 112-127. [CrossRef] [PubMed]

58. Hussain, M.; Ahmed, V.; Hill, B.; Ahmed, Z.; Taylor, S.D. A re-examination of the difluoromethylenesulfonic acid group as a phosphotyrosine mimic for PTP1B inhibition. Bioorg. Med. Chem. 2008, 16, 6764-6777. [CrossRef] [PubMed]

59. Nguyen, P.H.; Zhao, B.T.; Ali, M.Y.; Choi, J.S.; Rhyu, D.Y.; Min, B.S.; Woo, M.H. Insulin-mimetic selaginellins from selaginella tamariscina with protein tyrosine phosphatase 1B (PTP1B) inhibitory activity. J. Nat. Prod. 2015, 78, 34-42. [CrossRef] [PubMed]

60. Nguyen, P.H.; Ji, D.J.; Han, Y.R.; Choi, J.S.; Rhyu, D.Y.; Min, B.S.; Woo, M.H. Selaginellin and biflavonoids as protein tyrosine phosphatase $1 \mathrm{~B}$ inhibitors from Selaginella tamariscina and their glucose uptake stimulatory effects. Bioorg. Med. Chem. 2015, 23, 3730-3737. [CrossRef] [PubMed]

61. Ramírez-Espinosa, J.J.; Rios, M.Y.; Paoli, P.; Flores-Morales, V.; Camici, G.; Rosa-Lugo, V.D.L.; Hidalgo-Figueroa, S.; Navarrete-Vázquez, G.; Estrada-Soto, S. Synthesis of oleanolic acid derivatives: In vitro, in vivo and in silico studies for PTP-1B inhibition. Eur. J. Med. Chem. 2014, 87, 316-327. [CrossRef] [PubMed]

62. Thrasher, J. Pharmacologic Management of Type 2 Diabetes Mellitus: Available Therapies. Am. J. Med. 2017, 130, S4-S17. [CrossRef] [PubMed]

63. Safavi, M.; Foroumadi, A.; Abdollahi, M. The importance of synthetic drugs for type 2 diabetes drug discovery. Expert Opin. Drug Discov. 2013, 8, 1339-1363. [CrossRef] [PubMed]

64. Klopfenstein, S.R.; Evdokimov, A.G.; Colson, A.O.; Fairweather, N.T.; Neuman, J.J.; Maier, M.B.; Gray, J.L.; Gerwe, G.S.; Stake, G.E.; Howard, B.W.; et al. 1,2,3,4-Tetrahydroisoquinolinyl sulfamic acids as phosphatase PTP1B inhibitors. Bioorg. Med. Chem. Lett. 2006, 16, 1574-1578. [CrossRef] [PubMed] 
65. Puius, Y.A.; Zhao, Y.; Sullivan, M.; Lawrence, D.S.; Almo, S.C.; Zhang, Z.Y. Identification of a second aryl phosphate-binding site in protein-tyrosine phosphatase 1B: A paradigm for inhibitor design. Proc. Natl. Acad. Sci. USA 1997, 94, 13420-13425. [CrossRef] [PubMed]

66. Joshi, P.; Deora, G.S.; Rathore, V.; Tanwar, O.; Rawat, A.K.; Srivastava, A.K.; Jain, D. Identification of ZINC02765569: A potent inhibitor of PTP1B by vHTS. Med. Chem. Res. 2013, 22, 28-34. [CrossRef]

67. Rakse, M.; Karthikeyan, C.; Deora, G.S.; Moorthy, N.S.H.N.; Rathore, V.; Rawat, A.K.; Srivastava, A.K.; Trivedi, P. Design, synthesis and molecular modelling studies of novel 3-acetamido-4-methyl benzoic acid derivatives as inhibitors of protein tyrosine phosphatase 1B. Eur. J. Med. Chem. 2013, 70, 469-476. [CrossRef] [PubMed]

68. Sarmiento, M.; Zhao, Y.; Gordon, S.; Zhang, Z. Molecular basis for substrate specificity of protein-tyrosine phosphatase 1B. J. Biol. Chem. 1998, 273, 26368. [CrossRef]

69. Lipinski, C.A.; Lombardo, F.; Dominy, B.W.; Feeney, P.J. Experimental and Computational Approaches to Estimate Solubility and Permeability in Drug Discovery and Develop ment Settings. Adv. Drug Deliv. Rev. 1997, 23, 3-25. [CrossRef]

70. Veber, D.F.; Johnson, S.R.; Cheng, H.; Smith, B.R.; Ward, K.W.; Kopple, K.D. Molecular Properties That Influence the Oral Bioavailability of Drug Candidates. J. Med. Chem. 2002, 45, 2615-2623. [CrossRef] [PubMed]

71. Egan, W.J.; Merz, K.M.; Baldwin, J.J. Prediction of drug absorption using multivariate statistics. J. Med. Chem. 2000, 43, 3867-3877. [CrossRef] [PubMed]

72. Drwal, M.N.; Banerjee, P.; Dunkel, M.; Wettig, M.R.; Preissner, R. ProTox: A web server for the in silico prediction of rodent oral toxicity. Nucleic Acids Res. 2014, 42, 53-58. [CrossRef] [PubMed]

73. Sander, T.; Freyss, J.; Von Korff, M.; Rufener, C. DataWarrior: An open-source program for chemistry aware data visualization and analysis. J. Chem. Inf. Model. 2015, 55, 460-473. [CrossRef] [PubMed]

74. Valdez, J.; Cedillo, R.; Hernández-Campos, A.; Yépez, L.; Hernández-Luis, F.; Navarrete-Vázquez, G.; Tapia, A.; Cortés, R.; Hernández, M.; Castillo, R. Synthesis and antiparasitic activity of 1H-benzimidazole derivatives. Bioorg. Med. Chem. Lett. 2002, 12, 2221-2224. [CrossRef]

75. Flores-Carrillo, P.; Velázquez-López, J.M.; Aguayo-Ortiz, R.; Hernández-Campos, A.; Trejo-Soto, P.J.; Yépez-Mulia, L.; Castillo, R. Synthesis, antiprotozoal activity, and chemoinformatic analysis of 2-(methylthio)-1H-benzimidazole-5-carboxamide derivatives: Identification of new selective giardicidal and trichomonicidal compounds. Eur. J. Med. Chem. 2017, 137, 211-220. [CrossRef] [PubMed]

76. Hernández-Campos, A.; Ibarra-Velarde, F.; Vera-Montenegro, Y.; Rivera-Fernández, N.; Castillo, R. Synthesis and Fasciolicidal Activity of 5-Chloro-2-methylthio-6-(1-naphthyloxy)-1H-benzimidazole. Chem. Pharm. Bull. 2002, 50, 649-652. [CrossRef]

77. Velázquez-López, J.M.; Hernández-Campos, A.; Yépez-Mulia, L.; Téllez-Valencia, A.; Flores-Carrillo, P.; Nieto-Meneses, R.; Castillo, R. Synthesis and trypanocidal activity of novel benzimidazole derivatives. Bioorg. Med. Chem. Lett. 2016, 26, 4377-4381. [CrossRef] [PubMed]

78. Soria-Arteche, O.; Castillo, R.; Hernández-Campos, A.; Hurtado-de la Peña, M.; Gabriel Navarrete-Vázquez, G.; Medina-Franco, J.L.; Gómez-Flores, K. Studies on the Selective S-Oxidation of Albendazole, Fenbendazole, Triclabendazole, and other Benzimidazole Sulfides. J. Mex. Chem. Soc. 2005, 49, 353-358.

79. Goldstein, B.J.; Bittner-Kowalczyk, A.; White, M.F.; Harbeck, M. Tyrosine Dephosphorylation and Deactivation of Insulin Receptor Substrate-1 by Protein-tyrosine Phosphatase 1B. J. Biol. Chem. 2000, 275, 4283-4289. [CrossRef] [PubMed]

80. Téllez-Valencia, A.; Najera, H.; Sampedro, J.; Aguirre, B.; Olivares, V.R.A. Diseño de fármacos antiparasitarios. Inhibición especie específica de la triosafosfato isomerasa de Leishmanía mexicana. Boletín Inf. los Serv. Salud del Estado Hidalgo 2006, 29, 2-3.

81. Schrödinger Release 2014-1: LigPrep, version 2.9; Schrödinger: New York, NY, USA, 2014.

82. Madhavi Sastry, G.; Adzhigirey, M.; Day, T.; Annabhimoju, R.; Sherman, W. Protein and ligand preparation: Parameters, protocols, and influence on virtual screening enrichments. J. Comput.-Aided Mol. Des. 2013, 27, 221-234. [CrossRef] [PubMed]

83. Ghattas, M.A.; Atatreh, N.; Bichenkova, E.V.; Bryce, R.A. Protein tyrosine phosphatases: Ligand interaction analysis and optimisation of virtual screening. J. Mol. Graph. Model. 2014, 52C, 114-123. [CrossRef] [PubMed]

84. Friesner, R.A.; Banks, J.L.; Murphy, R.B.; Halgren, T.A.; Klicic, J.J.; Mainz, D.T.; Repasky, M.P.; Knoll, E.H.; Shaw, D.E.; Shelley, M.; et al. Glide: A New Approach for Rapid, Accurate Docking and Scoring. 1. Method and Assessment of Docking Accuracy. J. Med. Chem 2004, 47, 1739-1749. [CrossRef] [PubMed] 
85. Friesner, R.A.; Murphy, R.B.; Repasky, M.P.; Frye, L.L.; Greenwood, J.R.; Halgren, T.A.; Sanschagrin, P.C.; Mainz, D.T. Extra Precision Glide: Docking and Scoring Incorporating a Model of Hydrophobic Enclosure for Protein-Ligand Complexes. J. Med. Chem. 2006, 49, 6177-6196. [CrossRef] [PubMed]

86. Shelley, J.C.; Cholleti, A.; Frye, L.L.; Greenwood, J.R.; Timlin, M.R.; Uchimaya, M. Epik: A software program for pKa prediction and protonation state generation for drug-like molecules. J. Comput.-Aided Mol. Des. 2007, 21, 681-691. [CrossRef] [PubMed]

87. Schüttelkopf, A.W.; Van Aalten, D.M.F. PRODRG-A tool for highthroughput crystallography of protein-Ligand complexes. Acta Crystallogr. 2004, 60, 1355-1363.

88. Van Der Spoel, D.; Lindahl, E.; Hess, B.; Groenhof, G.; Mark, A.E.; Berendsen, H.J.C. GROMACS: Fast, flexible, and free. J. Comput. Chem. 2005, 26, 1701-1718. [CrossRef] [PubMed]

89. Kumari, R.; Kumar, R.; Source, O.; Discovery, D.; Lynn, A. g_mmpbsa-A GROMACS Tool for High-Throughput MM-PBSA Calculations. J. Chem. Inf. Model. 2014, 54, 1951-1962. [CrossRef] [PubMed]

Sample Availability: Samples of the compounds are not available from the authors. 